for those who intend to make their careers in the teaching of domestic science, in institutional management, and in various branches of scientific research.

\section{Sub-Fossil Hekla Pumice from Denmark}

Prof. A. NOE-NygaARD has written a paper on the "Sub-Fossil Hekla Pumice from Denmark" (Medd. Dansk Geol. For., 12, Heft 1, 35 ; 1951), in which is reproduced a photograph showing immense fields of drifting pumice in the sea off the Westmann Islands only a few days after the beginning of the Hekla eruption of March 1947. Hekla and several other volcanoes in the south of Iceland have emitted many flows of a uniform type of oversaturated glassy basalt; but investigations during the past decade have proved that intermediate to acid rocks are also represented to a considerable extent in the Hekla volcanic area, and that lavas and ashes of like composition, especially andesitic pumice, were ejected during the eruption of 1947. Prof. Noe-Nygaard has investigated the finds of sub-fossil pumice which have been made at three places in North Jutland. T'his pumice is of intermediate composition and is almost identical in chemical composition and petrography with andesitic pumice and ash from the recent eruption of Hekla, as well as with similar finds of sub-fossil pumice on the coasts of western Norway, Novaya Zemlja, Spitsbergen and Greenland. It is therefore taken as highly probable that these pumices were derived from former eruptions of volcanoes in the Hekla region. A question thus arises as to the age of the beds in which the sub-fossil pumice has been found. In Jutland the pumice fragments are associated with rolled pieces of wood, lignite, hazel nuts, small pieces of amber, and one fragment of dopplerite-all light materials capable of floating in currents and liable to drifting and stranding on coasts. One of the beds is covered with peat of the Sub-boreal period. In western Norway the pumice bed is found on the uppermost Tapes-line, by which the time of the eruption that supplied the pumice can be fixed at about 2000 B.c. Hence it is probable that four thousand years ago the Hekla volcanoes were erupting material of a nature and composition similar to their present products. Prof. Noe-Nygaard finally envisages the possibility of establishing a synchronous level in the Quaternary beds of several Atlantic coasts by means of the Hekla pumice, in addition to the pollen analyses and archæological considerations which have hitherto been used for chronological purposes.

\section{Ornithological Congress at Bamburgh}

A BRITISH ornithological conference was held at Bamburgh, Northumberland, during June 26-July I, under the joint auspices of the British Ornithologists' Union and the British Trust for Ornithology, local arrangements being in the hands of Dr. E. A. R. Ennion, director of the Monks' House Bird Observatory and Field Centre. Emphasis in the programme was on the field excursions. Members of the conference were able to visit the Farne Islands, which are National Trust bird sanctuaries with unique sea-bird colonies, and other interesting half-day visits were paid to Hulne Park, Alnwick, and to Chillingham and Ross Castle, where there is a memorial to Lord Grey of Fallodon. An all-day excursion was made to the Cheviot to see Northumbrian moorland habitats, and various short excursions were also made by small parties to other interesting localities. It is believed that at least 110 species were identified in the field during the conference, a striking indication of the wealth and variety of bird-life in north Northumberland. The indoor sessions, which took place in the Pavilion immediately below Bamburgh Castle, a setting specifically enhanced by the presence, on the rock face above, of several pairs of nesting fulmars, consisted of three discussions, six papers and two illustrated talks. The discussions, on fighting and threat in birds, on visible migration and on sea-bird populations, were led by Dr. N. Tinbergen, Colonel R. Meinertzhagen and James Fisher, respectively. The titles of the papers were as follows: high-watermark ecology (E. A. R. Ennion), observations on the hawfinch (Guy Mountfort), the work of the Madingley Ornithological Field Station of the Department of Zoology, University of Cambridge (W. H. Thorpe), observations on the lapwing (K. G. Spencer), Northumberland birds (G. W. T'emperley) and papertearing by birds (W. M. Logan Home). For his talk on "The Ornithological Year in Yorkshire", Mr. Ralph Chislett used some of his own fine collection of slides, and the other talk, on "The Pied Flycatcher at the Nest", by Bruce Campbell, was illustrated with slides from photographs by John Markham. In addition, members were entertained during one evening by Dr. and Mrs. Ennion at Monks' House, where the various trapping devices and other equipment of the Bird Observatory were demonstrated.

\section{French Bibliographical Digest: Physics and Chem- istry}

Nos. 7 and 8 of "The French Bibliographical Digest", which have recently been issued (No. 7, pp. 87 ; No. 8, pp. 72 . New York : French Embassy, 1951), deal with physics and chemistry respectively and complete the first series of bibliographical digests devoted to scientific works published in France during 1940-48. Several works published in the French language by Belgian and Swiss men of science are also included. A second series will list works published during 1949-51. The booklets contain, in addition to a useful list of the appropriate French scientific periodicals and publishers' addresses, the titles, with full bibliographical references, of the more important physics or chemistry books of university or more advanced standard. The inclusion of doctorate theses is most valuable. Many of the titles are accompanied by reviews, in English, reprinted by permission from British, American and French scientific journals. No prices are quoted because of the rapid fluctuations in exchange value. Prof. Y. Rocard, a member of the advisory board of the "Digest", contributes an introduction to No. 7, in which he describes briefly the effects of the German occupation on French physical research. He pays tribute to the many physicists, including $H$. Abraham, E. Bloch, G. Bruhat, F. Holweck, I. Cartan and J. Solomon, who died. either in concentration camps or because of their participation in the resistance movement. Finally, he surveys briefly post-war activities and mentions the various French laboratories and the branches of research being pursued there. The chemistry booklet is similar in lay-out to the one on physics. The arrangement is alphabetical by authors under the following headings: chemistry, general; organic chemistry ; inorganic chemistry ; analytical chemistry ; physical chemistry ; industrial chemistry, technology and metallurgy ; colloid chemistry ; and biochemistry. Librarians, as well as research workers, will find the two booklets extremely useful for reference purposes. 